\title{
Electrolytes in Selected Tissues of Heterobranchus bidorsalis Treated With Sub lethal Levels of Cypermethrin ${ }^{1}$ Gabriel, U.U; ${ }^{2}$ Jack, I.R.; ${ }^{3}$ Edori, O.S.; and ${ }^{2}$ Egobueze, E.
}

\begin{abstract}
s
Heterobranchus bidorsalis (mean length $31.50 \pm 2.32 \mathrm{~cm}$ SD; mean weight $241.25 \pm 30.39 \mathrm{~g}$ SD) was exposed to cypermethrin $(0.0005,0.0075,0.010,0.125$ and $0.0150 \mathrm{ppm})$ for 23 days to determine the effect of exposure on cations (sodium, $\mathrm{Na}^{+}$, potassium, $\mathrm{K}^{+}$) and anion, $\mathrm{Cl}$ in the gill, kidney, liver and muscle tissue. Hyponatraemia $(p>0.05)$ occurred in the gill except at $0.0075 p p m$ with hypernatraemia $1107.33 \%$ above control value, $105.63 \pm 7.48 \mathrm{mmol} / \mathrm{l})$. Hypokaelamia was recorded at 0.005 and $0.0150 \mathrm{ppm}$, but concentration dependent hyperkalaemia at 0.0075 through $0.0125 \mathrm{ppm}$. Gill of exposed fish had hypochlorinaemia except at 0.010ppm. Generally, kidneys of exposed fish had hyponatraemia and hypokaelamia relative to the respective control values. There was no change in $\mathrm{Cl}$ level at 0.0125 and $0.0150 \mathrm{ppm}$, but hypochlorinaemia at $0.005 \mathrm{ppm}$ and hyperchlorinaemia at 0.0075 and $0.010 p p m$ with 10.78 and $67.09 \%$ respectively, above the control value $(19.75 \pm 4.50 \mathrm{mmol} / \mathrm{l})$. In the liver, $\mathrm{Na}^{+}$levels were lower at $0.0025,132.50 \pm 55.00 \mathrm{mmol} / \mathrm{l}$ and $0.0125 \mathrm{ppm}$, $206.25 \pm 96.20 \mathrm{mmol} / \mathrm{l}$, whereas at $0.005,0.010$ and $0.015 \mathrm{ppm}$ it was 2.96 (96.36\%), 1.49 (48.45\%) and 1.70times (70.00\%) the control value, $275.00 \pm 27.66 \mathrm{mmol} / \mathrm{l}$. Hypokaelamia was recorded at 0.005 and $0.0075 \mathrm{ppm}$, whereas hyperkaelamia was noted at the other exposure concentrations with a peak at $0.0150 p p m, 23.61 \%$ the control value, $18.00 \pm 2.94 \mathrm{mmol} / \mathrm{l}$. Non-concentration dependent hyperchlorinaemia with about two units above control recorded at $0.0075-0.0125 p p m$ and about six units at 0.005 and $0.0150 p p m$ (Table 3). In the muscle, sodium, potassium and chloride ions were all elevated $\left(\mathrm{Na}^{+}, 72.66 ; \mathrm{K}^{+}, 4.14 ; \mathrm{Cl}^{+}, 54.22 \%\right)$ above their respective control values at $0.005 \mathrm{ppm}$. Generally hyponataemia, hypokaelamia and hypochlorinaemia were recorded in the other exposure levels. The study indicates that pollutants interfere with electrolyte in the organism thereby disrupting the internal physiology of the exposed fish.
\end{abstract}

Key words: Cypermethrin, electrolytes, Heterobranchus bidorsalis, tissues

\section{Introduction}

Yuman interference with the

habitat fragmentation with the resultant effect of landscape changes that culminates in the decline of wild life species (Ricklefs, 1997; Pough et al., 1998). The use of xenobiotics in agriculture as anaesthetics, growth promoters, aquatic vegetation control, predatory fauna eradicator, disinfectants and therapeutics for fish pest and diseases are found sometimes to affect non target species (Schnick, 1999). These chemicals are used intended to increase agricultural produce to alleviate food shortage problems leads to environmental conditions that fail to meet physiologic requirements of especially non-target species leading to stress (Allender et al., 2006; Al-Ghanim et al., 2008). This may increased circulating levels of glucocorticoids, causing immune suppression (Oppliger et al., 1998) resulting in vulnerability to pathogens.

Synthetic pyrethroid insecticides are extensively used to replace organochlorine, organophosphates and carbamates to control various types of pests and increase agricultural products. Unfortunately, these chemicals are also found to be potentially toxic to aquatic species (Reddy and Bashamohideen, 1998).
According to Beat et al. (1997) all pyrethroid insecticides are neurotoxic and act on the axons in the peripheral and central nervous systems. They interfere with sodium channels and the permeability of nerve cells, thereby affecting the transmission of nerve impulses across the neurons (Chukwu and Auta, 2007).

Pyrethroids are lipophilic in a nature and therefore have high rate of gill absorption which contributes to the sensitivity of fish to their exposure (Rukiye et al., 2003). Cypermethrin (cyano(3-phenoxy phenyl) methyl-3(2,2-dichlorovinyl)-,2-

dimethylcyclopropane carboxylate) is a synthetic pyrethroid which causes excitability and convulsion in organisms through the inhibition of gamma-aminobutyric acid (GABA) receptors in nervous system (Ramadan 1988). It altered the levels of calcium, phosphorus, sodium and tested protein in rainbow trout (Atamanalp et at., 2002) and the lengthen the depolarizatrion phase in first through the blockade of sodium channels of the various nerve filaments thereby affecting the travel of impulse (Bradbury and Coats, 1989; Hayes, 984). The electrolytes are involved in maintenance of the buffer systems in order to provide the proper acido-basic 
balance in the body tissues of animals (Tella, 2005). They also help in the regulation of the proper functioning of the heart and other muscle and also involved in redox (electron transfer) processes and co-factors for enzymes (Mohanty and Mishra, 1983).

Due to off-target movement of chemicals, which is unavoidable, and the resultant effects of these xenobiotics on aquatic biota, this study was their carried out to examine the electrolytic changes associated with cypermethrin toxicity in the commercial catfish, Heterobranchus bidorsalis (Fam. : Clariidae).

\section{Materials and Methods}

Heterobranchus bidorsalis (mean length, $31.50 \pm 2.32 \mathrm{cmSD}$; mean weight $241.25 \pm 30.39 \mathrm{gSD})$ were obtained from Ellah Lakes in Obrikom in Ogba-Egbema-Ndoni Local Government area of the rivers state. They were transported to the site of the experiment (Department of Chemistry Laboratory, Rivers State University of science and Technology, Port Harcourt, Nigeria) in a plastic container. The fish were acclimated individually in $30 l$ aquarium with $10 l$ effective volume for 14 days and fed at one percent biomass on a $35 \%$ crude protein diet. The water was changed daily and the aquarium washed with a piece of foam. Each treatment level had four replicates.

The fish was then exposed individually to sub-lethal concentrations $(30 l)$ of cypermethrin $(0.005,0.0075,0.010,0.125$ and $0.0150 \mathrm{ppm})$ prepared in borehole water (characteristics: temperature, $26.51 \pm 2.10^{\circ} \mathrm{C}$; dissolved oxygen, $\quad 4.51 \pm 0.51 \mathrm{mg} / \mathrm{l} ; \quad \mathrm{pH}$, $6.49 \pm 0.21$; alkalinity, $17.30 \pm 3.16 \mathrm{mg} / \mathrm{l}$ and hardness, $16.00 \pm 2.06 \mathrm{mg} / \mathrm{l}$ ) and a control of $0.00 \mathrm{ppm}$ for 23 days based on the procedure in APHA, (1989). Fresh solutions were prepared daily and feeding was done as in the acclimation. At the end of the experimental period, the fish was killed with a blow on the head and the organs of interest (liver, kidney and gill) and muscle tissue were excised. Samples of the $(0.5 \mathrm{~g})$ removed were ground in a mortar, mixed with $5 \mathrm{ml}$ of deionized water and centrifuged for ten minutes at $3000 \mathrm{rpm}$. The supernatant was decanted into plan bottles and stored at $-2^{\circ} \mathrm{C}$ for analysis. The samples were then analyzed for the electrolytes namely sodium, potassium and chlorides based on the colorimetric endpoint techniques described by
Schales and Schales (1941). The data obtained were subjected to analysis of variance (ANOVA) and where difference existed in the means they were by Duncan's multiple range test, DMRT (Zar, 1984).

\section{Results}

The gill exhibited a general decrease $(p<0.05)$ in the levels of sodium ions except at $0.0075 \mathrm{ppm}$ where a rise of $107.33 \%$ above the recorded control value, $105.63 \pm 7.48 \mathrm{mmol} / l$. (Table 1). Potassium levels declined at 0.005 and $0.0150 \mathrm{ppm}$, below the control value, $12.75 \pm 5.52 \mathrm{mmol} / 1$, but gradually rose from $10.82,14.75$ and $33.33 \%$ at 0.0075 through $0.0125 \mathrm{ppm}$. The chemical caused hypochlorinaemia in the gill of exposed fish except at $0.010 \mathrm{ppm}$ (Table 1). Kidneys of exposed fish had hyponatraemia and hypokaelamia relative to the respective control values $\quad\left(\mathrm{Na}^{+}, \quad 247.50 \pm 21.79 \mathrm{mmol} / \mathrm{l} ; \quad \mathrm{K}^{+}\right.$, $21.88 \pm 1.48 \mathrm{mmol} / 1)$, except with a rise $\mathrm{K}^{+}$at $0.0125 \mathrm{ppm}$ and at $0.015 \mathrm{ppm}$ with level equal to that in the control (Table 2). The chemical did not cause any change in $\mathrm{Cl}^{-}$at 0.0125 and $0.0150 \mathrm{ppm}$, hypochlorinaemia at $0.005 \mathrm{ppm}$ (11.39\% below control) and and hyperchlorinaemia at 0.0075 and $0.010 \mathrm{ppm}$ with 10.78 and $67.09 \%$ respectively above the control value $(19.75 \pm 4.50 \mathrm{mmol} / \mathrm{l})$. In the liver, $\mathrm{Na}^{+}$levels were lower at 0.0025 , $132.50 \pm 55.00 \mathrm{mmol} / 1$ and $0.0125 \mathrm{ppm}$, $206.25 \pm 96.20 \mathrm{mmol} / 1$, whereas at $0.005,0.010$ and $0.015 \mathrm{ppm}$ it was $2.96(96.36 \%), 1.49$ $(48.45 \%)$ and 1.70 times $(70.00 \%)$ the control value, $275.00 \pm 27.66 \mathrm{mmol} / \mathrm{l}$. Hypokaelamia was recorded at 0.005 and $0.0075 \mathrm{ppm}$, whereas hyperkaelamia was noted at the other exposure concentrations with a peak at $0.0150 \mathrm{ppm}, 23.61 \%$ the control value, $18.00 \pm 2.94 \mathrm{mmol} / 1$.

Non-concentration dependent hyperchlorinaemia with about two units above control recorded at $0.0075-0.0125 \mathrm{ppm}$ and about six units at 0.005 and $0.0150 \mathrm{ppm}$ (Table $3)$. In the muscle, sodium, potassium and chloride ions were all elevated $\left(\mathrm{Na}^{+}, 72.66 ; \mathrm{K}^{+}\right.$, $4.14 ; \mathrm{Cl}^{+}, 54.22 \%$ ) above their respective control values at $0.005 \mathrm{ppm}$ (Table 4). Generally hyponataemia, hypokaelamia and hypochlorinaemia were in the other exposure levels.

\section{Discussion}

In an attempt to define and measure the effects of pollutants on aquatic organisms, 
biomarkers and bio-indicators are employed on several studies on xenobiotics. The principle of this approach being the analysis of the physiological and biochemical responses of the organism to the pollutant, to which it was exposed (Jee and Kang, 2005). According to Bradifield and Rees (1978), toxicants act by the disruption of cell membrane permeability replacing the structural or electrochemical important elements in the cell which cause functional failure.

Sodium and potassium is the major cation of the extracellular fluid and $\mathrm{K}^{+}$chloride being the major anion of the intracellular fluid (Adegoye, 2007). The levels of sodium and potassium ions in the selected organs and tissue of $H$. bidorsalis were either higher or lower than the control value- a reflection of changes in the fluxes of these electrolytes as a result of cypermethrin toxicosis. Sodium and potassium are essential for the activity of many enzymes and have been implicated in the transport of ATP which participates in several metabolic processes. $\mathrm{Na}^{+}$and $\mathrm{K}^{+}$ATpase, are located in the cell membrane has been found to be involved in the active transport of $\mathrm{Na}^{+}$and $\mathrm{K}^{+}$across the cell membrane (Rajanna et al., 1981). Changes in these ions may indicate damage to the gills and the kidney (Oluwole, 2001). The author observed that slight increase in sodium and potassium ions may favour improvement in the renal function which is achieved through the re-adsorption of these ions from the blood by the kidney. Accordingly, the author postulated that renal re-adsorption of these electrolytes helps in the relieve of hypertension in humans. This may also apply to the fish since the electrolytes play the same roles in both organisms.

Reduction of $\mathrm{Na}^{+}$ion level may affect the heart functions of experimental fish and cause neurotoxic damage to the central nervous system (CNS) of the experimental fish (Luskova et al., 2002). Changes in these ions References

Adeoye A. (2007). A Testbook for Medical laboratory Practice. $1^{\text {st }}$ Edition. 238pp.

Al-Ghanim, A.K., Al-Kahem, H.F. Al-Akel, S.A., Al-Misned, F. and Ahmad, Z. (2008). Ethological response and haemotological and biochemical profiles of carp (Cyprinus carpio) exposed to trichlorfon. Journal of Food, Agriculture and Environment 6(3/4): 473-479. Allender, C.M., Mitchell, A.M., Philips, A. C., Gruszynski, K. and Beasley, R.V. (2006).

Haematology, plasma biochemistry and may be an indication of the disruption of the structural integrity of the gills and impending death under prolonged exposure to the chemical. According to Cox (1996) cypermethrin alters nerve impulse travels along in the nerves of vertebrates and other animals. The nerves become momentarily permeable to sodium atoms, thus allowing it to flow into nerves. It also delays the closing of the gate that allows the sodium flow (Vijverberg and Van den Bercken, 1990), which eventually results in multiple nerve impulses instead of the usual single. In turn, these impulses cause the nerve to release the neurotransmitter, acetylcholine and then stimulate other nerves (Eechs, 1992). Multiple impulses may result in convulsion in the exposed fish.

Chloride ion as the major extracellular fluid in the body combines with sodium to form $\mathrm{NaCl}$ (sodium chloride) which then helps in the osmotic balance of the organism (Adeoye, 2007). Increase or decrease $\mathrm{Cl}^{-}$ion has been associated with handling stress (Tomasso et al., 1980) and kidney disease. A mild decrease in chloride ion has been attributed to gill injury (Byme et al., 1989) and loss of chloride across the gills due to damage from toxicant exposure. Increase chloride may also arise from over-activity of the parathyroid glands.

Electrolyte concentrations indicate fishes' ability to osmoregulate and this is often compromised with stress, disease or gill lesions that increase gill permeability to ions (McDonald and Milligan 1992) or lateral line imbalance and hormonal disorder by affective endocrine organs through pesticide attack. Electrolytes had been shown to play a central role in gaseous exchange and intercompartmental water balance (Tella, 2005), therefore elevated or low levels may result in hyper or hyper function of the organ or tissues under study (Finco, 1989).

antibodies of select viruses in wild-caught Eastern Messauga, rattlesnakes (Sistrurus catanatus catenatus) from Illinois. Journal of Wildlife Disease, 42(1):107-114.

Atamanalp, M., Keles, M., Haliloglu, I.H. and Aras S.M. (2002). The effects of cypermethrin (a synthetic pyrethroid) on some biochemical parameters (Ca, P, Na and $\mathrm{TP}$ ) of rainbow trout (Oncorhynchus mykiss). Turk. J. Vet. Animal Sc. 26:1157-1160. 
Beat, G., Andres, W., Gunter, S. and Marc, S. (1997). The pyrethroids permethrin and cyhalothrin are potent inbibitors of the mitochondrial complex 1. J. Pharmacol. Exp. Ther. 281: 855.-

Bradbury, S.P. and Coats, J.R. (1989). Toxicokinetics and toxico-dynamics of pyrethroid insecticides in fish. Environ. Toxicol. Chem. 8:373-380.

Bradifield, R.E. and Rees, C.E. (1978). The impact of toxic pollutants. Effluents and Water Treatment Journal 18:61-81.

Byme, P., Speare, D. and Ferguson, H.W. (1989). Effects of cationic detergent on the gills and blood chemistry of rainbow trout, Salmon gairdneri. Dis. Aquat. Org. 61:185196.

Cox, C. (1996). Cypermethrin. Journal of

Pesticide Reform 16(2):15-20.

Eells, J.T. (1992). Pyrethroid insecticide induced alterations in mammalian synaptic membrance potential. J. Pharmacol. Exper Ther. 262:1173-1181.

Hayes, H.A. (1994). Principles and methods of toxiocology. Raven Press, New York. 1468pp. Finco, D.R. (1989). Kidney function. In: Clinical biochemistry of domestic animals. $4^{\text {th }}$ ed. J.J. Kanekoo Ed., Academic Press Inc. San Diego, California. Pp. 496-537.

Jee, H.J. and Kang, C.J. (2005). Biochemical challenges of enzymatic defense system after phenanthrene exposure in Olive flounder, Pralichthys olivaceus. Physiol. Res. 54:585591.

Luskova, V., Svoboda, M. and Kolarova, J. (2002). The effect of diazinon on blood plasma biochemistry in Carp (Cprinus carpio L.). Acta Vet. Brno. 71:117-123.

McDonald, D. G. and Milligan, C.L. (1992). Chemical Properties of blood. In: Hoar, W.S., Randall, D. J. and Farrell, A.P. eds. Fish Physiology, 12B, The Cardiovascular system. New York Academic Press, 56-135.

Mohanty, B.K. and Mishra, B.N. (1983).

Effects of mercurial drug (Kajyoli) on albino rat blood. J. Environ. Biol. 4(4):201-206.

Okechukwu, O.E. and Auta, J. (2007). The

effects of sub-lethal doses of lamda-

cyhalothrin on some biochemical

characteristics of the African catfish clarias gariepinus. Journal of Biological Sciences, 7(8):1473-1477.

Oluwole, S.F. (2001). Effects of garlic on some heam-atological and biochemical parameters. African Journal of Biomedical
Resaerch, 4:139-141.

Oppliger, A., Clobert, J., Lecomte, J., Lorenzon, P., Boudjemadi, K. and John-Alder, H. (1998).Environmental stress increases the prevalence and intensity of blood parasite, infection in the common lizard Lacerta vivipara. Ecology Letters, 1:129-138. Pough, F. H., Andrews, R.M., Cadle E.J., Crump, M.L. Savitisky, A.H. and Wells, D. K. (1998). Herpetology. Prentice Hall, Upper Saddle River, New Jersey, 575 pp. Rajanna, B., Chapatwala, K.D., Vaishnav, D.D. and Desaiah, D. (1981). Changes in ATpase activity in tissues of rat fed on cadmium. J. Environ. Biol. 2(1):1-9. Ramadan, A.A. (1988). Action of pyrethroids on GABA receptors function. Pest. Biochem. Physiol. 32:97-105.

Reddy, P.M. and Bashamohideen, M. (1989). Fenvalerate and Cypermethrin induced changes in haematological parameters of Cyprinus carpio. Acta Hydrochim. Hydrobiol. 17:101-107

Ricklefs, R.E. (1997). The economy of nature $4^{\text {th }}$ ed. W.H. Freeman and Company, NY. 678pp.

Rukiye, V., Figen, U.E., Hilal., P. and Oner, K. (2003). Investigation of acute toxicity of deltamethrin on guppies (Poecilia reticularta). Ecotoxicol. Environ. Safety. 55:82-85.

Schales, O. and Sehales, S.S. (1941). A simple and accurate method for the determination of chloride ion in biological fluid. J. Biol. Chem. 140:879-884.

Schnick, R. A. (1999). Use of chemicals in fish management and fish culture: Past and future, In Smith D. J., Gingerich, W. H. and Barker, M.G. B. (eds). Xenobiotics in fish. Kluwer Academic Publisher, New York.

Tella, M.A. (2005). Serum electrolyte changes in West African dwarf (WAD) sheep with single or concurrent (Bebesia ovis and Trypanosome congolense) infections. African Journal of Biological Research 8:63-65.

Tomasso, J.R., Davis, K.B. and Parker, N.C. (1980). Plasma Corticosteroid and electrolyte dynamics of hybrid striped bass (White bass $\mathbf{x}$ striped bass) during netting and hauling. Proc. World Maricult. Soc. 1:303-310.

Vijverberg, H.P.M. and Van den Bercken, J. (1990). Neurotoxological effects and mode of action of Pyrethroid insecticides. Rit. Rev.

Toxicol. 21:105-120.

Zar, H.K. (1984). Statistical tools for scientific analysis. Oxford Publishers, London, 310pp. 
Table 1. $\mathrm{Na}^{+}, \mathrm{K}^{+}$and $\mathrm{Cl}^{-}$ions in the gill of Heterobranchus bidorsalis exposed to various concentrations of cypermethrin for 23 days

\begin{tabular}{|c|c|c|c|c|c|c|}
\hline $\begin{array}{c}\text { Conc. of } \\
\text { cypermethrin } \\
(\mathbf{p p m})\end{array}$ & $\mathbf{N a}^{+}(\mathbf{m m o l} / \mathbf{L})$ & $\begin{array}{c}\text { \% of } \\
\text { Control }\end{array}$ & $\mathbf{K}^{+}(\mathbf{m m o l} / \mathbf{L})$ & $\begin{array}{c}\text { \% of } \\
\text { Control }\end{array}$ & $\mathbf{C l}^{-}(\mathbf{m m o l} / \mathbf{L})$ & $\begin{array}{c}\text { \% of } \\
\mathbf{C o n t r o l}\end{array}$ \\
\hline 0.00 & $105.63 \pm 7.25^{\mathrm{a}}$ & 100.00 & $12.75 \pm 4.52^{\mathrm{ab}}$ & 100.00 & $39.63 \pm 33.61^{\mathrm{ab}}$ & 100.00 \\
\hline 0.005 & $89.75 \pm 3.26^{\mathrm{a}}$ & 84.97 & $11.13 \pm 0.95^{\mathrm{b}}$ & 87.29 & $21.88 \pm 8.75^{\mathrm{c}}$ & 55.21 \\
\hline 0.0075 & $219.00 \pm 38.09^{\mathrm{a}}$ & 207.33 & $14.13 \pm 3.42^{\mathrm{ab}}$ & 110.82 & $35.75 \pm 14.86^{\mathrm{ab}}$ & 90.21 \\
\hline 0.010 & $67.50 \pm 3.95^{\mathrm{a}}$ & 63.90 & $14.63 \pm 1.03^{\mathrm{ab}}$ & 114.75 & $45.88 \pm 2.86^{\mathrm{a}}$ & 115.77 \\
\hline 0.0125 & $97.25 \pm 11.68^{\mathrm{a}}$ & 92.07 & $17.00 \pm 2.74^{\mathrm{a}}$ & 133.33 & $35.13 \pm 16.13^{\mathrm{ab}}$ & 88.64 \\
\hline 0.0150 & $37.38 \pm 2.04^{\mathrm{a}}$ & 35.39 & $12.50 \pm 5.21^{\mathrm{ab}}$ & 98.04 & $25.38 \pm 9.20^{\mathrm{c}}$ & 64.04 \\
\hline
\end{tabular}

Means with the same superscript in the same column are not significantly different $(\mathrm{P}<0.05)$

Table 2. $\mathrm{Na}^{+}, \mathrm{K}^{+}$and $\mathrm{Cl}^{-}$in the kidney of Heterobranchus bidorsalis exposed to various concentrations of cypermethrin for 23 days

\begin{tabular}{|c|c|c|c|c|c|c|}
\hline $\begin{array}{c}\text { Conc. of } \\
\text { cypermethrin. } \\
(\mathbf{p p m})\end{array}$ & $\mathbf{N a}^{+}(\mathbf{m m o l} / \mathbf{L})$ & $\begin{array}{c}\text { \% of } \\
\text { Control }\end{array}$ & $\mathbf{K}^{+}(\mathbf{m m o l} / \mathbf{L})$ & $\begin{array}{c}\text { \% of } \\
\text { Control }\end{array}$ & $\mathbf{C l}^{-}(\mathbf{m m o l} / \mathbf{L})$ & $\begin{array}{c}\text { \% of } \\
\mathbf{C o n t r o l}\end{array}$ \\
\hline 0.00 & $247.50 \pm 21.79^{\mathrm{a}}$ & 100.00 & $21.88 \pm 1.49^{\mathrm{a}}$ & 100.00 & $19.75 \pm 4.50^{\mathrm{ab}}$ & 100.00 \\
\hline 0.005 & $132.50 \pm 5.50^{\mathrm{a}}$ & 53.54 & $20.38 \pm 1.55^{\mathrm{a}}$ & 93.14 & $17.50 \pm 0.00^{\mathrm{ab}}$ & 88.61 \\
\hline 0.0075 & $160.00 \pm 6.35^{\mathrm{a}}$ & 64.65 & $19.38 \pm 7.33$ & 88.57 & $21.88 \pm 8.75^{\mathrm{ab}}$ & 110.78 \\
\hline 0.010 & $105.00 \pm 0.00^{\mathrm{a}}$ & 42.42 & $20.75 \pm 3.07^{\mathrm{a}}$ & 94.84 & $33.00 \pm 1.83^{\mathrm{a}}$ & 167.09 \\
\hline 0.0125 & $216.25 \pm 15.79^{\mathrm{a}}$ & 87.37 & $23.13 \pm 0.85^{\mathrm{a}}$ & 105.71 & $19.75 \pm 4.50^{\mathrm{ab}}$ & 100.00 \\
\hline 0.0150 & $142.50 \pm 7.50^{\mathrm{a}}$ & 57.58 & $21.88 \pm 2.50^{\mathrm{a}}$ & 100.00 & $19.75 \pm 4.50^{\mathrm{ab}}$ & 100.00 \\
\hline
\end{tabular}

Means with the same superscript in the same column are not significantly different $(\mathrm{P}<\mathrm{O} .05)$

Table 3. $\mathrm{Na}^{+}, \mathrm{K}^{+}$and $\mathrm{Cl}^{-}$in the liver of Heterobranchus bidorsalis exposed to various concentrations of cypermethrin for 23 days.

\begin{tabular}{|c|c|c|c|c|c|c|}
\hline $\begin{array}{c}\text { Conc. of } \\
\text { cypermethrin. } \\
(\mathbf{p p m})\end{array}$ & $\mathbf{N a}^{+}(\mathbf{m m o l} / \mathbf{L})$ & $\begin{array}{c}\text { \% of } \\
\text { Control }\end{array}$ & $\mathbf{K}^{+}(\mathbf{m m o l} / \mathbf{L})$ & $\begin{array}{c}\text { \% of } \\
\text { Control }\end{array}$ & $\mathbf{C l}^{-}(\mathbf{m m o l} / \mathbf{L})$ & $\begin{array}{c}\text { \% of } \\
\mathbf{C o n t r o l}\end{array}$ \\
\hline 0.00 & $275.00 \pm 27.17^{\mathrm{ab}}$ & 100.00 & $18.00 \pm 2.94^{\mathrm{ab}}$ & 100.00 & $33.13 \pm 11.43^{\mathrm{a}}$ & 100.00 \\
\hline 0.005 & $815.00 \pm 81.12^{\mathrm{a}}$ & 296.36 & $17.63 \pm 2.75^{\mathrm{ab}}$ & 97.94 & $195.75 \pm 28.66^{\mathrm{a}}$ & 590.85 \\
\hline 0.0075 & $132.50 \pm 5.50^{\mathrm{c}}$ & 48.18 & $16.75 \pm 1.71^{\mathrm{b}}$ & 93.06 & $50.50 \pm 2.79^{\mathrm{a}}$ & 152.43 \\
\hline 0.010 & $408.75 \pm 7.62^{\mathrm{ab}}$ & 148.45 & $20.25 \pm 4.56^{\mathrm{ab}}$ & 112.50 & $46.75 \pm 2.33^{\mathrm{a}}$ & 141.11 \\
\hline 0.0125 & $206.25 \pm 9.62^{\mathrm{c}}$ & 75.00 & $20.88 \pm 1.44^{\mathrm{ab}}$ & 116.00 & $58.63 \pm 13.62^{\mathrm{a}}$ & 176.97 \\
\hline 0.0150 & $467.50 \pm 15.15^{\mathrm{ab}}$ & 170.00 & $22.25 \pm 4.01^{\mathrm{a}}$ & 123.61 & $189.63 \pm 26.05^{\mathrm{a}}$ & 572.38 \\
\hline
\end{tabular}

Means with the same superscript in the same column are not significantly different $(\mathrm{P}<0.05)$.

Table 4. $\mathrm{Na}^{+}, \mathrm{K}^{+}$and $\mathrm{Cl}^{-}$in the muscle of Heterobranchus bidorsalis exposed to various concentrations of cypermethrin for 23 days

\begin{tabular}{|c|c|c|c|c|c|c|}
\hline $\begin{array}{c}\text { Conc. of } \\
\text { cypermethrin. } \\
(\mathbf{p p m})\end{array}$ & $\mathbf{N a}^{+}(\mathbf{m m o l} / \mathbf{L})$ & $\begin{array}{c}\text { \% of } \\
\text { Control }\end{array}$ & $\mathbf{K}^{+}(\mathbf{m m o l} / \mathbf{L})$ & $\begin{array}{c}\text { \% of } \\
\text { Control }\end{array}$ & $\mathbf{C l}^{-}(\mathbf{m m o l} / \mathbf{L})$ & $\begin{array}{c}\text { \% of } \\
\mathbf{C o n t r o l}\end{array}$ \\
\hline 0.00 & $333.75 \pm 18.02^{\mathrm{a}}$ & 100.00 & $24.13 \pm 3.42^{\mathrm{a}}$ & 100.00 & $103.75 \pm 6.17^{\mathrm{a}}$ & 100.00 \\
\hline 0.005 & $576.25 \pm 83.61^{\mathrm{a}}$ & 172.66 & $25.13 \pm 2.39^{\mathrm{a}}$ & 104.14 & $160.00 \pm 23.36^{\mathrm{a}}$ & 154.22 \\
\hline 0.0075 & $240.00 \pm 20.34^{\mathrm{a}}$ & 71.91 & $22.63 \pm 7.44^{\mathrm{a}}$ & 93.78 & $35.00 \pm 1.15^{\mathrm{a}}$ & 33.73 \\
\hline 0.010 & $233.75 \pm 37.50^{\mathrm{a}}$ & 70.04 & $22.00 \pm 3.88^{\mathrm{a}}$ & 91.12 & $82.50 \pm 9.37^{\mathrm{a}}$ & 79.52 \\
\hline 0.0125 & $105.00 \pm 0.00^{\mathrm{a}}$ & 31.46 & $22.13 \pm 5.20^{\mathrm{a}}$ & 91.71 & $89.95 \pm 11.48^{\mathrm{a}}$ & 86.91 \\
\hline 0.0150 & $178.75 \pm 9.05^{\mathrm{a}}$ & 53.56 & $24.50 \pm 1.78^{\mathrm{a}}$ & 101.53 & $29.13 \pm 9.73^{\mathrm{a}}$ & 28.08 \\
\hline
\end{tabular}

Means with the same superscript in the same column are not significantly different $(\mathrm{P}<\mathrm{O} .05)$ 